\title{
Of Eden and Nazareth: Stories to capture the imagination
}

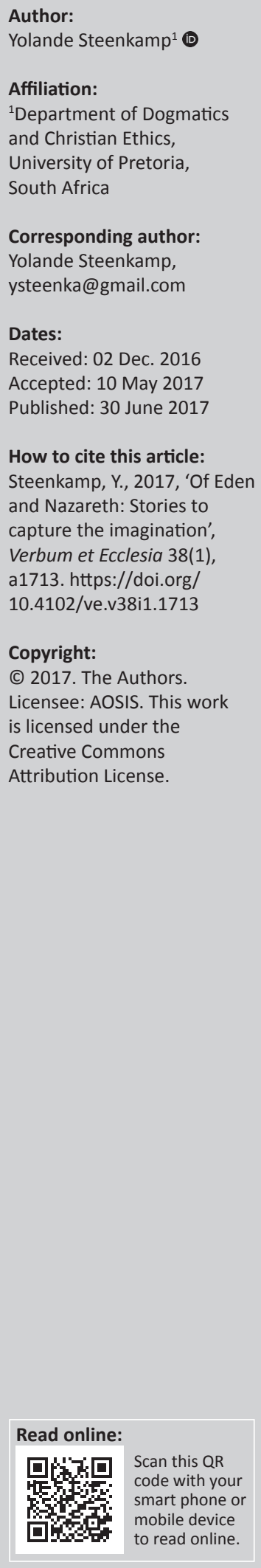

In pursuit of counter-traditions that have read the Eden narrative without subscribing to the Christian fall-redemption paradigm, this article engages Richard Kearney's hermeneuticalphenomenological reading of the imagination to explore new avenues for imagining sin and salvation along post-metaphysical lines. The first section provides insights proceeding from an intratextual reading of the Eden narrative. The second section proceeds to incorporate the biblical and rabbinical concept of the yetser to elaborate the reading described above. The section follows Kearney's reading of the Eden narrative to elicit the imagination along ethical lines as humanity's passion for the possible. The third section reads the annunciation narrative along these same lines, illustrating how a divine kingdom of justice and love is possibilised by an imagination captured by divine promise and hospitality. By reading these two narratives together through the lense of the imagination, novel ways of rethinking sin and salvation along post-metaphysical lines emerge that portray salvation as human participation in God's ongoing creation of justice and love, thus enabling the God Who May Be.

Intradisciplinary and/or interdisciplinary implications: This article is relevant to the fields of philosophy, philosophy of religion and theology. The narratives of fall and promise, previously read by philosopher Richard Kearney in different contexts and not in relation to one another, are read here from a decidedly theological point of view.

\section{Introduction}

The interpretation of sin in the history of the doctrine of the Church, and correspondingly the understanding of salvation in Christ, has been profoundly influenced by the Greek metaphysical tradition and its emphasis on ontology (Steenkamp 2016). This article will explore ways of re-imagining sin and salvation through a hermeneutical re-reading of certain counter-traditions in Scripture. As such, we will re-read the narratives of Eden and the Annunciation through the lense of the yetser, an Old Testament (OT) and Talmudic concept of imagination. What results is an eschatological reinterpretation of salvation (and the Christ event) in terms of the Messianic Kingdom of the God Who May Be. ${ }^{1}$

\section{Of Eden: Imagination towards death}

The Garden of Eden narrative has fascinated its readers - both inside and outside religion - for centuries. Yet, it is a story that needs to be salvaged from a long and heavy shadow cast over it by its history of interpretation. Christian readings of the story over the centuries have been largely conditioned by the hamartiological reductionism that characterises the fall-redemption paradigm as the dominant metanarrative of mainstream Christianity. The narrative's interpretation in Christianity has for the most part been based on New Testament (NT) and patristic perspectives and as such has become a narrative of condemnation and a tool for control, especially of women (cf. Stewart 2012:46). There have, however, been counter-traditions that have either not subscribed to the idea that the narrative supports the doctrine of original sin, or that have viewed what is usually considered 'the fall' as symbolic of a great triumph for humanity. ${ }^{2}$

\footnotetext{
1.A recent proposal for a post-metaphysical re-imagination of God has come from the Irish philosopher Richard Kearney in his widely acclaimed monograph, The God who may be: A hermeneutics of religion (2001). Writing as a philosopher, and approaching his subject matter mainly by means of phenomenology and hermeneutic returns to biblical texts, Kearney invites theologians to contribute to the discussion from a specifically theological point of view. This article forms part of a larger research project that aims to accept Kearney's invitation and address both the challenges and opportunities posed to Christian theology by such a post-metaphysical re-reading of invitation and address both the challenges and opportunities posed to Christian theology by such a post-metaphysical re-reading of God (cf. Steenkamp 2011, 2012, 2011, 2012; cf. Gratton \& Manoussakis 2007a; Kearney \& Zimmermann 2015; Manoussakis 2006 fo an overview of Kearney's impact in the philosophical, theological and literary worlds). Specifically, the study investigates the implications
of post-metaphysical reimaginings of God for the theological categories of hamartiology and soteriology.

2.See, for example, Tikva Frymer-Kensky's note on Eve as Prometheus, 'the bringer of culture (fire) for humanity, who was punished by the gods' (1990:275-276). See also Reicke (1956:198-199) and his emphasis on human procreation as a principle of civilisation. A further example would be the Gnostic traditions, which understood the serpent as God's divine messenger, and considered the serpent as good and Eve as heroine for grasping the insight provided by the eating of the fruit. See Philip Alexander's study on the Eden narrative in Gnostic literature for a thorough discussion (1992:91-104)
} 
Reading the narrative on its own terms, ${ }^{3}$ however, and taking into account both its rich mythological undertones and its rich literary landscape, the reader finds their imagination captured by the ambivalence of a narrative that perpetually refuses a final, definitive interpretation. ${ }^{4}$ Any discussion about 'sin' based on the Eden narrative needs to take place along the lines of mistrust and disobedience of God, resulting in fractured relationships and estrangement on all levels - from God, from each other, from some animals and from nature (Toews 2013:14; cf. Goldingay 2003:144). Such a relational view of sin and its effects is far removed indeed from the ontological understanding of sin that developed under the influence of the Western Church Fathers (Toews 2013:14). Neither the Eden narrative, nor any other biblical text, speaks of Adam and Eve bringing about the 'fall' of the human race. Instead, the mythonarratological prologue to Genesis tells 'not just one but a sequence of stories' that in combination attempt to provide some explanation for:

how wrongdoing came to dominate the human story in ways that affect people's relationship with God (Gen 3), with their family and society (Gen 4) and with supernatural powers (Gen 6). (Goldingay 2003:144) ${ }^{5}$

\section{Richard Kearney and the Eden narrative in terms of the yetser}

In The wake of the imagination: Toward a postmodern culture, Kearney takes a historical approach to illustrate that the human ability to 'image' or 'imagine' has been mainly understood in the history of Western thought as a representational faculty (reproducing images of some pre-existing reality) or as a creative faculty (producing images which often lay claim to an original status in their own right) (1988:15). Tracing the views of imagination from the Hebraic and Greek cultures through Medieval and modern perspectives, to the postmodern voices of structuralism, post-structuralism and deconstruction, he illustrates how the:

... creative power of imagination which biblical culture identified with Adamic man, and Greek culture with Promethean or demiurgic man, reaches its ultimate humanist conclusion with existentialist man. And the logical implication would seem to be

3.The doctoral thesis that this article reflects devoted an entire chapter to a contextual (historical, mythological and literary) interpretation of the Eden narrative. Because of space constraints, a few notes must suffice.

4.As a multilayered text, the Eden narrative draws on many images and symbols that open multiple possibilities of meaning. The hermeneutical challenge consists in the fact that the same character or entity may be interpreted in different ways (Kruger 2001a:55). We must therefore assume that the multiplicity in the images is intentional and avoids reducing these rich symbols to one specific meaning in the intentional and avoids reducing these rich symbols to one specific meaning in the
interest of one supposedly intended purpose of the narrative (both of which interest of one supposedly intended purpose of the narrative (both of which
scholars have been notoriously unable to agree on). The many allusions to the wisdom tradition in the narrative adds the further ambiguous notion that humanity's newly acquired moral awareness and self-consciousness result in expulsion from paradise, echoing the pessimistic wisdom tradition's view that wisdom disappoints (Hendel 2013:41). This is a narrative that resists one dimensionality in every way.

5.Toews' emphasis on what is not present in the text is significant in light of the excessive theological content that has been piled and projected onto this text and its interpretation in its rather complex Wirkungsgeschichte. This includes a complete lack of any association of the serpent with Satan or the demonic; the absence of sexual connotations; and the absence of words such as 'sin', 'transgression', rebellion' or "guilt'. Nowhere is it implied that Adam's moral condition suffers or is altered as a result of the disobedience, or that the sin of Cain in Genesis 4 should be understood in view of 'a morally defective nature that he inherited from Adam' (2013:13). The narrative does not mention a 'fall', that is, that 'later Christian understanding which has been read back into the text' (2013:13). that the human imagination will disappear as man himself disappears. The concept of imagination cannot, apparently, survive the postmodern age of deconstruction. (Kearney 1988:30)

Because of the decisive influence of the biblical heritage on Western culture, Kearney begins his study of the genealogy of the imagination with an interpretative exploration of the book of Genesis (Kearney 1988:38). He reads the Eden narrative through the window of the 'good and evil yetser', a term for human creativity that is a usurpation of the divine yetzirah, and which first appears in the OT in the Adamic myth, where it marks the fall of humanity into history (Gratton \& Manoussakis 2007b:xvii; Kearney 1988:39):

The story of imagination is as old as the story of creation itself. In Genesis it is suggested that the birth of the human power of imagining coincides with Adam's transgression of God's law. The Original Sin of our first parents marks imagination from its inception. The Knowledge of Good and Evil, which the serpent promises will make Adam and Eve "like gods," is henceforth identified with man's ability to imagine a world of his own making - a world of striving, desire, remorse and death which began with the fall from paradise into history. The Adamic myth of the first book of the Bible tells the tale of a fallen imagination. And, as we shall see, it is above all else an ethical tale. (Kearney 1988:39)

Derived from the root yzr (רצ), ${ }^{6}$ Kearney interprets the yetser as the human person's 'creative impulse to imitate God's own creation' (Kearney 1988:39). Associated with the yetser is both an ethical consciousness of good and evil and an historical consciousness of past and future. Thus, Adam and Eve's eating of the fruit does not only impart knowledge of good and evil but also marks the beginning of time, enabling humanity to 'project itself into the future through its creative activity' (Gratton \& Manoussakis 2007b:xvii).

Drawing from the exegetical tradition of Rabbinic and kabbalistic sources, Kearney sees in humanity's yetser a likeness to the stigma of a stolen divine possession (e.g. the Promethean myth; Kearney 1988:41). The essential ambiguity of imagination is made plain by the fact that the freedom acquired by Adam and Eve's exercise of their yetser was both a liberation and curse: 'Split between his present being and his future possibilities of becoming, the First Man feels torn inside, out of joint with himself' (Kearney 1988:41):

This loss of innocence, of contentedness with being what he is, is the cost of the freedom to become more than he is, to make himself other than his given self, to imagine alternative possibilities of existence. But the curse of shame, anguish, labour and death which Adam's sin entails also contains an ironic blessing. In his presumptuous bid to equal God his father, the human son loses Eden and gains history. (Kearney 1988:42)

This means that yetser is intimately related to the freedom of human beings to narrate their being as a choice between good and evil. Thus, Kearney designates the yetser as a 'passion for the possible' that enables human existential

6.See the discussions by Otzen (1990:257-265) and Schmidt (1971:761-765). 
experience (Kearney 1988:42; cf. Gratton \& Manoussakis 2007b:xvii). ${ }^{7}$

The Talmud almost consistently offers a negative evaluation of the yetser as the 'evil inclination or impulse' (צר הרע'; yetser harah), following the notion in Genesis 6:5 that '... every inclination of the thoughts of their hearts (yetser) was only evil continually'. ${ }^{8}$ These negative views advocate the suppression of the imaginative impulse represented by the yetser. The yetser harah is often identified with the human corporeal nature, and especially linked with sexual desire (Kearney 1988:44). ${ }^{9}$ The Talmud associates bodily lust with the yetser because of the part it was understood to have played in Eve's disobedience and 'subsequent fall into the historical order of sexual procreation and shame' (Kearney 1988:44; cf., e.g., Sanh 43b; Gn Rab 27; Yal Shim Gn 44; Ta'an 24a; y Ned 41b).

Rabbinic literature thus reveals a suspicion of imagination as a drive towards idolatry, coupled with a particular antagonism towards the associated bodily desire (Kearney 1988:45). The essential ambiguity of imagination remains intact, however, because the Talmudic suppression of the yetser only emphasises the fact that it is God who created humanity with this trait, and, moreover, that humanity shares this trait with the divine (Kearney 1988:45). Biblical tradition, furthermore, attaches a twofold character to the word yetser as both the human form and human nature. While the first was created by God, the latter could be regarded as something which God made (e.g. Ps 103:14), or as something which the human person creates or performs (Dt 31:21; Porter 1901:108-109).

This twofold nature of the yetser in the OT opens the possibility of a more benign view of the imagination, found in an alternative Rabbinic tradition that Kearney calls the 'tradition of integration'. A number of Talmudic passages address the inherent tension of imagination, attempting to integrate the evil imagination into a good imagination (Kearney 1988:46; cf. Ber 61a; Gn Rab 48, 226; cf. Otzen 1990:265): ${ }^{10}$

In its admission of a fundamentally good possibility for the yetser, this Talmudic body of opinion suggests a more lenient logic behind God's creation of man as a creature of imagination.

7.Kearney (1998) explains the relation to existentialism: "Man's ability to project imaginatively into the future opens up an infinite horizon of possibilities. He no longer lives in the immediacy of the actual moment. And so no longer present to himself, he is cast out into the chaos of a free-floating existence. (Indeed existence as the existentialist thinkers of our own century understand it - ex-sistere, standing out beyond oneself in a process of endless self-surpassing - may be said to hav begun with the birth of imagination....) The yetser is evil to the extent that man lose all sense of belonging or direction, living according to his own way rather than according to God's way.... In short, the human imagination becomes subject to evil in that it falls victim to its own idolatrous creations. Freed from the necessity of a divinely ordered reality, the First Man faces the arbitrariness of his own imaginings' (p. 43).

8.Genesis 6:5, '....' וכל־יצר מחשבת לבו רק רע כל־היום:'

9.In his thorough study of the yetser, Frank Porter cautioned against the temptation, because of the influence of Hellenistic dualism, to connect the yetser harah to the body, and yetser hatob (the good inclination) to the soul, 'making them expressions of the character of two equally essential parts of man. Rather it is the nature of man as a whole that is in mind, and in it the evil tendency, or disposition, dominates' as a whole that is
(Porter 1901:109).

10.See also suggestions in the OT that the imagination may be put to 'good' use, that is, Deuteronomy 31:21; 1 Chronicles 28:9; 29:18; as well as the command to love and worship God with the 'whole' soul (Kearney 1988:47).
According to this positive reading, imagination is deemed to be that most primordial 'drive' of man which, if sublimated and oriented towards the divine way (Talmud), can serve as an indispensable power for attaining the goal of creation: the universal embodiment of God's plan in the Messianic Kingdom of justice and peace. (Kearney 1988:46)

A human yetser that is redirected towards the fulfilment of divine will and purpose (i.e. the divine yetser $)^{11}$ may therefore become partner with God in the task of historical recreation (Kearney 1988:47). The possibility of such co-creation may explain why, after the sixth day of creation, having just created humanity with its yetser, God declares creation 'very good':

In short, if the evil imagination epitomizes the error of history as a monologue of man with himself, the good imagination (yetser hatov) opens up history to an I-Thou dialogue between man and his Creator. (Kearney 1988:47)

The yetser, in this view, is then in itself neither good nor evil, but may become either through human choice and action (Kearney 1988:48). Humanity is advised to turn to the Torah as guide in their efforts to submit the inclinations of the yetser to God's plan for creation (Kearney 1988:49). Unlike the negative interpretive view of the yetser, the integrative approach does not identify yetser harah with the body and yetser hatob with the soul, effectively rejecting body-soul dualism (Kearney 1988:49). Importantly:

The distinction between good and evil is seen as a moral choice rather than a physical property of being. And this emphasis on the ethical rather than ontological character of the imagination is regarded by several commentators as one of the main features which differentiate the Hebraic from the Hellenic understanding of this concept. According to this Talmudic tradition, evil does not pre-exist man, either as a form of cosmic being or as a preestablished given of his own corporeal being. Evil, like good, is seen in the context of man's ethical horizon of decision. (p. 49)

The fundamental ethical understanding of the imagination in the Semitic world returns us, Kearney concludes, to its fundamentally historical character (Kearney 1988:49). ${ }^{12}$ As it was by free choice that human imagination was made evil, the human person may also by choice make it good: 'Decision for the good results in the historical realization of man's yetser in accordance with the plan (yetser) of the Original Creator (Yoteor)' (Kearney 1988:51, citing B. Bat. 16a; Ber. 60b).

The ethical notion of goodness is thus linked in Hebraic thought with the historical notion of becoming. In contradistinction to Hellenic culture, this reveals a preference for the historical category of becoming over the ontological category

11.This is suggested, also, by the image of God as Potter. Of the crafts referred to in the OT with the root , almost always employ יצר in a theological context, referring to Yahweh as Potter and implying the creative activity of Yahweh as creator of humanity (or the smashing of pottery as divine judgement). Isaiah uses the image to suggest that God's creatures must subject themselves to divine will. 'Just as the work (yesser) of God's creatures must subject themselves to divine will. Just as the work (yesser) of against the will of the divine Creator' (Otzen 1990:259; cf. Schmidt 1971:764).

12.A significant use of yetser in this regard pertains to God's 'shaping' of history and may refer to divine purpose. See, for example, Isaiah 46:11, where Yahweh states, concerning Cyrus' advance, 'I have spoken, and I will bring it to pass; I have planned (יצר), and I will do it (עשה)' (Otzen 1990:264). 
of being (Kearney 1988:51, my emphasis). The implication is radical: the question is not whether the human person 'is' good (or evil) per se, but that he 'may become so', based on the free orientation of the yetser to either extreme. It also means that goodness is never obtained as a condition or state of existence, because it is irreducible to any single act in the present. Rather, goodness is an:

\begin{abstract}
... eschatological horizon which opens up the path of history as a dynamic movement towards the end (eschaton) or goal of perfect goodness - a goal which would only finally be realized in the arrival of the Messianic era, what Christianity later referred to as the Coming of the Kingdom.... Hence the Judeo-Christian teaching that goodness must not show itself in the sense of reducing itself to the realm of being here and now - for such is the way of pride and idolatry. Goodness, in the full sense, must always remain a promise, as it were beyond being, until the ultimate coming of the Messiah, that is, until man and God are fully reconciled at the end of time. (pp. 51-52)
\end{abstract}

Greek philosophy, moulded by the Hellenic understanding of time as circular, has no notion of the faculty of the will, as Hannah Arendt points out. In contrast, the Hebraic notion of history as creation (both human and divine), return and becoming - as a more linear path leading from a past to a future that may be altered by human intervention - introduces the concept of free will to Greek philosophy. Nevertheless, as opposed to the Hebrew concept of the yetser residing in the human person's free ethical choice, Greek philosophy still only manages to consider imagination from an epistemological point of view (Kearney 1988:52).

Kearney's analysis leads him to describe the Hebraic concept of imagination in terms of four fundamental properties: (1) mimetic - as a human imitation of the divine act of creation, (2) ethical - as a choice between good and evil, (3) historical as a projection of future possibilities of existence and (4) anthropological - as an activity that differentiates humankind from both a higher (divine) order and a lower (animal) order, and that 'opens up a freedom of becoming beyond the necessity of cosmic being' (Kearney 1988:53).

Kearney's reading of yetser as representing the human ability to freely choose between good and evil finds its theological precedents and parallels not only in typically Semitic views of $\sin$, but also in the trajectory of the Greek Church Fathers that would eventually be expressed in Pelagius' view that the human condition remained - even after Adam's sin - neutral and therefore with a capacity for both good and evil - a choice which could be freely made by a 'free and entirely undetermined will' (Berkhof 1969:132; cf. Steenkamp 2016:40-68; Toews 2013). ${ }^{13}$ We now turn to a narrative that illustrates the imagination (yetser) as power of the possible, along the same eschatological lines drawn by Kearney. While

13.It is worth noting that the OT seems to suggest a difference between the creative endeavours of humanity and divinity. God is the subject of two Hebrew verbs that
denote God's work of creation, where brh (ברא, priestly account) describes God's initial creation of heaven and earth, and yzr (ברא', Yרahwistic account) describes the acts of creation that follow by ordering pre-existing created elements. While the acts of creation that follow by ordering pre-existing created elements. While the
latter is used of both divine and human acts of creation or creativity, brh is reserved for the divine alone. This seems to imply a fundamental difference between Creator and creature: 'While man may be said to legitimately imitate God as Yotser in so far as his creative activities express his "good imagination" (yetser hatov), he in so far as his creative activities express his "good imagination" (yetser hatov), he
cannot presume to emulate God as a Creator ex nihilo (Bore)" (Kearney 1988:70).
Kearney interprets this narrative of the Annunciation in terms of hospitality to the Divine Stranger in his Anatheism (2011), it will be read here in a way that Kearney himself has not done (to my knowledge), namely in continuity with his interpretation of the yetser as 'power of the possible', and also in line with his proposal that God be re-imagined, postmetaphysically, as possibility, or the God Who May Be.

\section{Of Nazareth: Imagination towards life}

The short story of the Divine Messenger announcing the possibility of the Messiah's birth to a young girl in Nazareth seems rather obsessed with what we 'call' things. There are the more obvious, almost expected references to this, such as what people and places are called: Nazareth, Joseph and the young Mary (cf. 26d, 27c, 27d)..$^{14}$ There is the almost-familiar pronouncement of an unlikely pregnancy, ${ }_{1}^{15}$ along with a directive of what the child's name is 'to be called' (31c). 'Inбoṽ s. Yeshua (from ישע', 'to save'), denoting deliverance. A rather weighty name for a baby, yet it is soon outshined by the angel announcing that this baby will 'be called' 'Son of the Most High' (32b) and 'holy Son of God' (35e). The manner in which the angel addresses Mary leaves her perplexed: She is the 'favoured one'. This, along with the standard Greek greeting, both words derived from the root $\chi \alpha \rho-$, meaning 'favour' and 'grace', was certainly not the way a young girl, gripped in poverty, was commonly addressed. The text has a point to make: what we call things, and how we address people, 'matters'.

Most deeply, the narrative takes issue with 'what we call' or define as possible and impossible, and in the person of the young Mary it invites us to imagine again, so that the impossible may indeed become possible. The Strange Messenger is sent to Mary (26-27), addresses her three times (28; 30-33; 35-37), upon which she responds in kind, three times $(29 ; 34 ; 38 \mathrm{a}-\mathrm{c})$, before the angel leaves her (38d). The first two addresses by the angel leaves Mary confused. At first she is only perplexed by his highly favourable words towards her, a lowly child from a poverty-stricken town, and ponders his greeting. But his second address is so extravagant in its promises that Mary cannot but question the possibility of these things: How may this be? ${ }^{16}$

14.The structure $I$ have outlined in Figure 1 reflects the unfolding of the story as a dialogue framed by the arrival and departure of God's messenger. See also LaVerdiere (2004:viii-ix)

15.The announcement of an unlikely pregnancy is a familiar theme in the Israelite literary tradition. See, for example, Esther Fuch's detailed study of annunciation (and temptation) type-scenes of the biblical mother figure (Chapter 3 [2000:4490]). Typically, the type-scene is told entirely from the perspective of male characters, with the birth announcement often made to the husband instead of his wife, and involving the mother figure only insofar and up until she births the son who allows the story to move forward (Fuchs 2000:46). As such, 'the telos of nativity narratives is the birth of a male heir, and the happy re-establishment of patrilineal continuity' (Fuchs 2000:44). Also, '[t]he birth of the son leads to the inevitable mimetic and diegetic death of the mother. She will either die at childbirth, like Rachel, or, as happens most of the time, through the suppression of information' (p. 46)

Luke strays from this norm, however, in that the Annunciation is told entirely from Mary's perspective, includes the Magnificat, and in that Mary remains a character in Luke-Acts (Wilson 2012:512).

16.Kearney interprets Mary's being 'perplexed' at the angel's greeting, as well as her questioning response ('how may this be'), in terms of a hermeneutic wager that leaves her traversing the boundaries of fear and consent. Finding herself preceded by a literary tradition of birth announcements to unlikely mothers, this is very much 


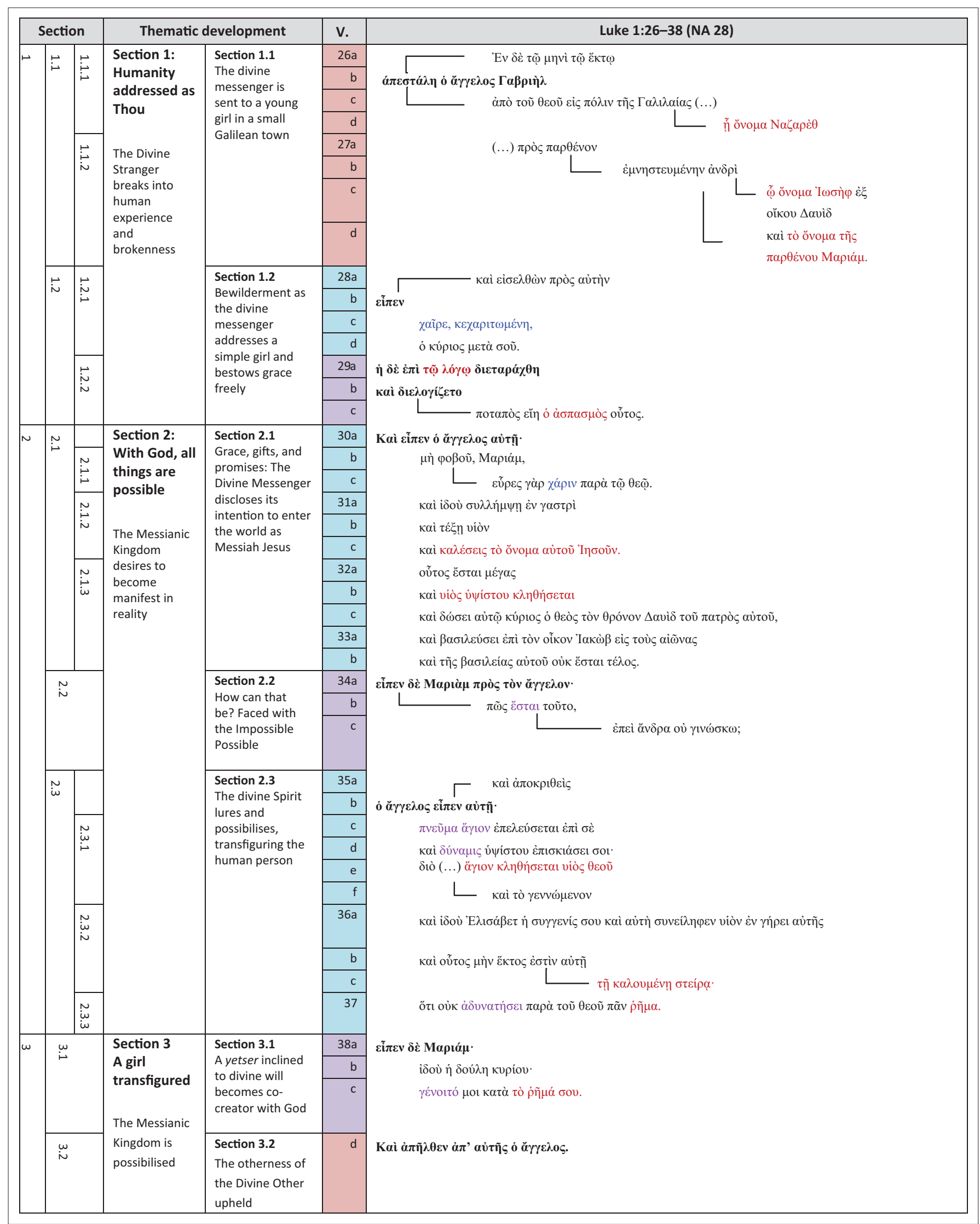

FIGURE 1: A structural and thematic analysis of the annunciation (Lk 1:26-38).

\section{(footnote 16 continues...)}

a hermeneutic dialogue between her own frightened heart and a tradition that has taught her how Divine Possibility may present itself as strange visitors, showing up unexpected and unannounced (Kearney 2011:24-25; cf. 2015a:220). The hermeneutic pause in encountering strangers and aliens is vital, because strangers are not always angels, as (footnote 16 continues...)

we clearly see from the mythical rendering of the temptation narratives of Jesus in the desert. See Kearney's discussion of Ricoeur's hermeneutic approach to hospitality, which 'argues for a prudent interpretation between different kinds of strangers' (Kearney 2015b:173-184 [175]). 
The third and final address by the Divine Stranger speaks to the young Mary of the possibilising power of the Spirit that will 'overshadow' her (35cd). This is poetic language, as we

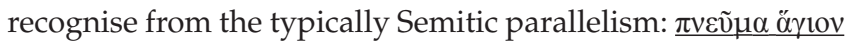

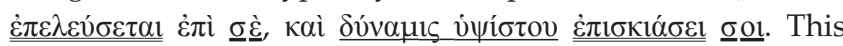
poetics of the possible is meant to capture Mary's imagination and transfigure her, so that she may become a window through which the Eternal may be actualised in time and space. The angel reminds Mary of Elizabeth, a family member, who even at an advanced age finds herself 6 months pregnant - she who 'had been called' barren. And if this was not enough to break through the boundaries of Mary's imagination, the angel concludes, 'See, with God nothing will be (or may be) impossible' (37). ${ }^{17}$

By the time Mary responds a third time, she has been transformed into an eschatological agent. At first a lowly and lonely child in a dire situation, ${ }^{18}$ the limits of her existence have been exploded by the poetic nudging of a Strange Visitor. At the end of this encounter, she has turned into an agent ( $\delta o v i \lambda \eta$, 'slave, servant') of the Divine, not entirely different from the angel - a Messenger of God - for Mary's body becomes the portal through which the Messiah steps into the world. Her final words are simple but filled with

17.Luke chooses words for the angel that are similar to those in Genesis 18:14a, where the divine visitors announce Sarah's pregnancy to Abraham: 'Is anything too wonderful for the Yahweh?' (היפלא מיהוה דבר).

18.The dire position to which I refer pertains to Mary's social status and the fact that she had likely fallen pregnant out of wedlock. As for her social status, the fact that she lived in Nazareth means that she formed part of a small agrarian community that was both extremely poor and looked down upon by other Palestinian, not to mention Judaean, towns (cf. Crossan 1995:26). Furthermore as a young, unmarried female, probably around 13 years of age, she had no standing in society. As for her pregnancy, the traditional view of Mary as virgin - even perpetual virgin in some cases, cf. Prot. Jas. - took shape amidst a patriarchy that enforced its values on women through the stories they told. As such, Mary was often pictured as a paragon of purity, a 'Second Eve' who corrects the mistakes of the first (Wilson 2012:512-513, 515; cf. Fornberg 2002:158; cf. e.g., Gambero [1999:51-58] for Irenaeus' description of the parallel between Eve and Mary along the same lines as Adam and Christ in Paul). The reality was no doubt very different. The emphasis on Mary's purity may probably be traced back to a Jewish polemic 'that identified Mary's purity may probably be traced back to a Jewish polemic 'that identified Mary as a harlot who conceived Jesus out of wedlock' (Wilson 2012:512-513; cf. Stewart 2012:49). While we simply lack the evidence that would shed any kind of light on the circumstances surrounding Mary's pregnancy, historical research does suggest that Jesus was an illegitimate child. It is vitally important for the interpretation of both the Annunciation and Jesus as Messiah that we recognis that we encounter in Mary and Jesus a mother and son who would have lived in utter poverty on the fringes of society. Van Aarde understands the fact that Jesus grew up 'fatherless in Galilee' (Joseph being a fictional character) as the very reason for his intimate relation to God as 'Father' (2001:119-134). It is regrettable that we have forfeited this perspective on the 'historical Mary', and I propose that theology boldly engages the theological implications of the likelihood that the one we call Messiah was not only naturally conceived, but also bore the brunt of his contemporaries for being shamefully illegitimate. We must engage hermeneutically with this perspective, since it illustrates that the Powerless Possible found expression in this world through a mother and child who would have been perceived as the lowliest and most unlikely vessels for divine grace. If we imagine pery as ase likely was: a pregnant girl ousted, suffering from me imagine Mary as she terrified, uneducated and alone, then' we may perhaps understand how the Divin Strang begin to appreciate just how radical her openness to the Divine Stranger really was. There is a subversive dunamis to this young pregnant girl that begs hermeneutic rediscovery (cf. Wilson 2012:516). Indeed, " $t$ ] he "dangerous memory" of the young woman and teenage mother Miriam of Nazareth, probably not more than twelve or thirteen years old, pregnant, frightened, and single ... can subvert the tales of mariological fantasy and cultural femininity. In the center of the Christian story stands not the lovely "white lady" of artistic and popular imagination kneeling in adoration before her son. Rather it is the young pregnant woman, living in occupied territory and struggling against victimization and for survival and dignity. It is she who holds out the offer of untold possibilities for different christology and theology' (Schüssler Fiorenza 2015:205-206).

See Maeckelberghe's hermeneutical study of Mary, especially the feminist reinterpretation of Mary as symbol, based on the hermeneutic contributions of Paul Ricoeur and Rosi Bridoti (1991). See also Fornberg's study of the reception paul Ricoeur and Rosi Braidottion (191). See also Fornberg's study of the reception history of the Annunciation, which proposes a new way forward by fresh ways of of humility but rather of strength and willpower in this world. In this way Mary becomes a pattern of life for all those who want to make justice a present reality in becomes a pattern of life for all thos dynamic potency, 'May it be with me according to your word'

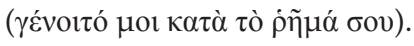

Let's linger here a moment, for the Greek is rich in subtle wordplay. First, there has been a development from the

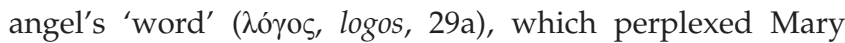
upon hearing the angel's greeting, to 'according to your word' ( $\dot{\rho} \tilde{\mu} \mu \alpha$, rhema, 38c). While logos and rhema really function as synonyms in the biblical text, our passage seems to imply development here in terms of the mere 'words' that the angel has spoken, to the weight of these words and the impact that they have had on Mary. Rhema follows in 38c upon the angel's use of the word, which is here better translated as no 'thing': 'For nothing ( $\pi \tilde{\alpha} \nu \dot{\rho} \tilde{\eta} \mu \alpha)$ will be impossible with God'. When the young Mary receives the Stranger, it seems she opens to, and is opened by, possibility.

Another striking - this time intertextual - wordplay suggests that Mary, in opening to divine will, becomes co-creator with God in God's continuing creation. The modal form of yivoual, 'come into being, become, happen' ( $\gamma \varepsilon \dot{v} v o \imath$ ó, 38c), may be translated as either 'let it be' or 'may it be'. Interestingly, a similar form of the same verb (though imperative rather than optative) appears as the word by which God creates in Genesis 1, 'Let it be' ( $\gamma \varepsilon v \eta \theta \eta \dot{\tau} \tau \omega$, lxx). It is also similar to the modal form of the Hebrew היה 'to be', found in the epiphany to Moses and translated by Kearney as 'I am who may be'. ${ }^{19}$

\section{Richard Kearney and the Divine Host-Stranger}

Richard Kearney considers the Annunciation in the first chapter of Anatheism, where he reflects on instances of hospitality to the Uninvited Guest from the three Abrahamic faiths. Encounters with the Divine Stranger in Scripture are marked either by hospitality or hostility. ${ }^{20}$ There is either an opening to or a withdrawing from, and when Mary responds to the divine invitation in 'the first act of Christian anatheism' 'thinking again, believing again, trusting again' - she bears a child and possibilises the advent of the Messiah (Kearney 2011:17, 24). Kearney appeals to Andrei Rublev's striking Icon of the Trinity (1411 CE), featuring three angels seated around an empty chalice:

... symbol of the gap in our horizons of time and space where the radically Other may arrive, unexpected and unknown. And this empty receptacle at the core of the circle is, arguably, none other than the womb-heart of Mary herself (khora). As the Greek

19.Kearney engages the important formula אהיה אשר אהיה (Ex 3:14) hermeneutically to suggest that the usual translation 'I am that I am' be adjusted to 'I am who may be'. The Hebrew has been translated into Greek as'Ey Latin as ego sum qui sum and into a variety of English forms, with 'I am who am' Latin as ego sum qui sum and into a variety of English forms, with 'I am who am'
and 'I am he who is' being the most common (Kearney 2001:22). Taking medieval Jewish commentator Rashi as hermeneutic point of departure, who translates the phrase from Exodus 3:14 as 'I shall be what I shall be', and interprets this name in terms of 'mandate and mission', Kearney argues for a more dynamic interpretation of God's self-disclosure. Moses' response to Yahweh's calling - 'here I am', signals that the 'name' should be read in the context of a dynamic mandate, pointing to the divine collaboration in the coming of justice on earth (Kearney 2001:26).

20.Kearney reminds us of the way Matthew (25:35-44) suggests the 'surprising divinity of the hospes', when Jesus identifies himself with 'the least of these', a 'stranger' who is welcomed or turned away: 'Eschatology is realized in the presence of the alien in our midst. Love of the guest becomes love of God. The cut comes, of the alien in our midst. Love of the guest becomes love of God. The cut comes, So it is not surprising that when Jesus, in another episode, is asked by the lawyer, 'who is my neighbor?' he replies with the story of the Good Samaritan - the alien "who is my neighbor?' he replies with the story of the Good Samaritan - the alien outsider who brings healing to the wounded and the
Theophany as the guest become host' (Kearney 2011:29). 
inscription of the Mother and Child Mosaic of the Monastery of the Khora in Istanbul reads: Khora akhoraton - 'Container of the Uncontainable'. Mary is the khora opening the heart of divinity. The aperture, without which, as in all human openings to the stranger, the sacred could not be embodied. (Kearney 2011:25-26)

The result is a captivating poetics of becoming. A young girl is met by a strange yet divine wager - the announcement of a would-be Messiah. She receives the Stranger as host, yet finds herself perplexed in the face of the seemingly impossible. The Divine Messenger entices her, however, to believe more, and so become more. Confronted by the One who may be, Mary finds herself transfigured by a poetics of the possible. Her imagination is so captivated - we could say that her yetser opens to Divine intention - that in the face of her 'yes', she becomes co-creator with God of a new, eschatological world. Having initially received the Stranger as hostess, she finds that she has become guest to the Stranger - witness to and partaker of God's initiative of continuous creation: 'The Nazarena's double response - to hosting the stranger's impossible love is perhaps our condition too?' (Kearney 2015a:222). This double hospitality expresses the paradox of the Powerless Possible: God as possibility, or as the 'impossibility of impossibility', is vulnerable to human response insofar as God may be God in the form of the eschatological Kingdom of love and justice. ${ }^{21,22}$ A human 'yes' to this divine wager at once turns the human host into guest as she is 'overshadowed' with the possibilising power of the Spirit, says Kearney:

\begin{abstract}
... divinity - as Father, Son, or Spirit - is described as a possibilizing of divine love and logos in the order of human history where it would otherwise have been impossible. In other words, the divine reveals itself here as the possibility of the Kingdom - or if you prefer to cite a via negativa, as the impossibility of impossibility. (Kearney 2007:52)
\end{abstract}

\section{Conclusion}

When read together through the lense of possibility, the narratives of Eden and the Annunciation illustrate Kearney's eschatological understanding of imagination as that whereby

\footnotetext{
21.Bernard of Clairvaux also expressed this sentiment in his Hom. 4, 8-9: Opera Omnia, Edit. Cisterc. 4 [1966]: 53-54: 'You have heard, O Virgin, that you will conceive and bear a son; ... The angel awaits an answer; ... In your brief response we are to be remade in order to be recalled to life.... Answer quickly, O Virgin. Reply in haste to the angel, or rather through the angel to the Lord. Answer with a word, receive the Word of God. Speak your own word, conceive the divine Word. Breathe a passing word, embrace the eternal Word; Open your heart to faith, O blessed Virgin, your lips to praise, your womb to the Creator. See, the desired of all nations is at your door, knocking to enter. If he should pass by because of you all nations is at your door, knocking to enter. If he should pass by because of you delay, in sorrow you would begin to seek him afresh, the One whom your soul loves. Arise, hasten, open. Arise in faith, hasten in devotion, open in praise and
thanksgiving. Behold the handmaid of the Lord, she says, be it done to me according to your word'.

22.See Paredes' monumental study of the Kingdom of God in relation to Mary. His contribution is extremely valuable - a 'theoretical-practical or, if you will, existential Mariology, that will be meaningful for Christian living' (Paredes 1991:12). Paredes has structured and organised his synthesis of Mariology according to the Kingdom of God as focal point of Jesus' teaching, for '(i)f all the expectations of the Old Testament were flowing towards this point, if the Church marches towards the eschatological completeness of God's Kingdom, then, it is also fitting to place the reflections on Mary in this context. ... From the horizon of God's Kingdom, people and institutions attain a surprising dynamism and an historical meaning. Mary is one of the central personages within the great project of the Kingdom of God one of the central personages within the great project of the Kingdom of God within that Kingdom which was initiated in her and which persists in history unti the day of its total unfolding. ... To place Mary in the context of the Kingdom of God, as the Woman who surrendered herself to it, leads us to contemplate on how its values and requirements were shaped in her. Thus, Mary acquires relevance for those who take the Kingdom of God as the inspiration and goal of their life. She becomes the paradigm of the Church that wants to be faithful to the dynamism that restores the Kingdom' (Paredes 1991:12-13).
}

humanity may become co-creators in the ongoing act of divine creation. The God Who May Be is closely tied to Kearney's interpretation of the kingdom, which is - in the case of the God of posse $e^{23}$ - never imposed or declared already accomplished from the beginning. Instead, it is by opening ourselves to the transfiguring power of transcendence that the God Who May Be offers each person the possibility of realising a promised kingdom and thus also to transfigure God in turn, 'by making divine possibility ever more incarnate and alive' (Kearney 2001:2).

If the dawn of the Messianic Kingdom of justice and love is seen as a divine act of salvation, then these two narratives illustrate that humanity, through its ability to 'imagine' and project itself into the future - either in alignment or opposition to the divine will - becomes the agents that enable God's Kingdom to come in physicality. This invites us to reimagine the entire Christ event, not only the baby's birth, as such an eschatological event. Christ, who submits his yetser to the will of the Father in an act of worshipful surrender, becomes the perfect embodiment of the Word of God to a humanity whose yetser is perpetually put in service of itself in an act of idolatry. The enabling of the Kingdom of God in Jesus, who embodies the human telos, captures the human imagination and transfigures humanity through the existential experience of transcendence which breaks into its concrete reality through the Christ event and its retelling. In this way, realising eschatology is possibilised through the imagination. Christ as prototype of the divinely intended telos of humanity becomes an existential possibility via the transfiguration, enacted by the imagination. This enables humanity to become co-creators with God of the new creation, or Kingdom of God. Such an interpretation proposes an eschatological approach to God (a God of posse) as an alternative to the omnipotent, omniscient and omnicausal God of metaphysics (the God of esse). Whereas the God of esse faces the discrediting of philosophy and is ever haunted by the conundrum of theodicy and is a God torn between his love for and his judgement of a humankind caught in a perpetually sinful state, the God of posse captures the free yetser of humankind and ever calls creation forward to its fulfilment in God's Messianic Kingdom of love and justice.

\section{Acknowledgements}

I wish to acknowledge Prof. Danie Veldsman, who was promotor of the doctoral research from which this article originated and Prof. Richard Kearney, for his generous guidance during his visit to South Africa in May 2017. Funding for this study was granted by the University of Pretoria (postgraduate bursary).

\section{Competing interests}

The author declares that she has no financial or personal relationships that may have inappropriately influenced her in writing this article.

23.Borrowing liberally from Nicholas of Cusa, Kearney calls the God of the possiblethe God Who May Be - the 'God of posse' (2001:2). 


\section{References}

Alexander, P.S., 1992, 'The fall into knowledge: The Garden of Eden/paradise in gnostic literature', in P. Morris \& D. Sawyer (eds.), A walk in the garden: Biblical, iconographical and literary images of Eden, pp. 91-104, Journal for the Study of the Old Testament Supplement Series 136, Sheffield Academic Press, Sheffield.

Berkhof, L., 1969, The history of Christian doctrines, The Banner of Truth Trust, London. Bernard of Clairvaux, 1966, 'Advent Sermons', Opera Omnia, Cistercian ed. 4, 182-185.

Crossan, J.D., 1995, Jesus: A revolutionary biography, HarperSanFrancisco, San Francisco, CA.

Fornberg, T., 2002, 'The annunciation: A study in reception history', in M. Müller \& $\mathrm{H}$. Tronier (eds.), The New Testament as reception, pp. 157-180, Journal for the Study of the New Testament: Supplement Series 230, Copenhagen International Seminar 11, Sheffield Academic Press, London.

Frymer-Kensky, T., 1990, 'The sage in the Pentateuch: Soundings', in J.G. Gammie \& L.G. Perdue (eds.), The sage in Israel and the ancient Near East, pp. 275-287, Eisenbrauns, Winona Lake.

Fuchs, E., 2000, Sexual politics in the biblical narrative: Reading the Hebrew Bible as a woman, Journal for the Study of the Old Testament: Supplement Series 210. Sheffield Academic Press, Sheffield.

Gambero, L.S.M., 1999, Mary and the Fathers of the Church: The blessed virgin Mary in Patristic thought, translated from the Italian original by T. Buffer, Ignatius Press, San Francisco, CA.

Goldingay, J., 2003, Israel's Gospel. Old Testament Theology, vol. 1., InterVarsity Press, Downers Grove, IL.

Gratton, P. \& Manoussakis, J.P. (eds.), 2007a, Traversing the imaginary: Richard Kearney and the postmodern challenge, Northwestern University Press, Evanston, IL.

Gratton, P. \& Manoussakis, J.P. (eds.), 2007b, 'Introduction: The miracle of imagining', in P. Gratton \& J.P. Manoussakis (eds.), Traversing the imaginary: Richard Kearney and the postmodern challenge, $\mathrm{pp}$. xvii-xxv, Northwestern University Press, Evanston, IL.

Hendel, R.S., 2013, The Book of Genesis: A biography, Lives of Great Religious Books. Princeton University Press, Princeton, NJ, viewed 05 December 2015, from http:// www.questia.com/read/120905982/the-book-of-genesis-a-biography

Kearney, R., 1988, The wake of imagination: Toward a postmodern culture, Routledge London. https://doi.org/10.4324/9780203430620

Kearney, R., 2001, The God who may be: A hermeneutics of religion, Indiana Series in the Philosophy of Religion, Indiana University Press, Bloomington.

Kearney, R., 2007, 'Re-imagining God', in J.D. Caputo \& M.J. Scanlon (eds.), Transcendence and beyond: A postmodern inquiry, pp. 51-65, Indiana University Press, Bloomington.

Kearney, R., 2011, Anatheism: Returning to God after God. Insurrections: Critical Studies in Religion, Politics, and Culture, Columbia University Press, New York.

Kearney, R., 2015a, 'Annunciation', Giornale di Metafisica 2, 220-222.

Kearney, R., 2015b, 'Hospitality: Possible or impossible?' Hospitality and Society 5/2-3(2015), 173-184. https://doi.org/10.1386/hosp.5.2-3.173_1
Kearney, R. \& Zimmermann, J. (eds.), 2015, Reimagining the Sacred: Richard Kearney Debates God with James Wood, Catherine Keller, Charles Taylor, Julia Kristeva, Gianni Vattimo, Simon Critchley, Jean-Luc Marion, John Caputo, David Tracy, Jens Zimmermann, and Merold Westphal. Insurrections: Critical Studies in Religion, Politics, and Culture, Columbia University Press, New York.

Kruger, H.A.J., 2001, 'Myth, ideology and wisdom: A brief survey', Old Testament Essays 14(1), 47-75.

LaVerdiere, E.S.S.S., 2004, The annunciation to Mary: A story of faith, Luke 1:26-38, Liturgy Training Publications, Chicago, IL.

Maeckelberghe, E., 1991, Desperately seeking Mary: A feminist appropriation of a traditional religious symbol, Kok Pharos Publishing House, Kampen.

Manoussakis, J.P. (ed.), 2006, After God: Richard Kearney and the religious turn in Continental philosophy, Perspectives in Continental Philosophy 49, Fordham University Press, New York.

Otzen, B., 1990, 'צר', in G.J. Botterweck \& H. Ringgren (eds.), Theological dictionary of the Old Testament, vol. 6, pp. 257-265, trans. D.E. Green, William B. Eerdmans Publishing Company, Grand Rapids, MI.

Paredes, J., 1991, Mary and the Kingdom of God: A synthesis of mariology, St Paul Publications, Middlegreen.

Porter, F.C., 1901, The yeçer hara: A study in the Jewish doctrine of sin, Scribner, New York.

Reicke, B., 1956, 'The knowledge hidden in the tree of paradise', Journal of Semitic Studies 1(3), 193-201. https://doi.org/10.1093/jss/1.3.193

Schmidt, W.H., 1971, 'צר jṣr formen', in E. Jenni \& C. Westermann (eds.), Theologisches Handwörterbuch zum Alten Testament, vol. 1, pp. 761-765, Chr. Kaiser Verlag, München.

Schüssler Fiorenza, E., 2015, Jesus: Miriam's Child, Sophia's Prophet: Critical issues in feminist Christology. Cornerstones, 2nd edn., Bloomsbury T\&T Clark, London.

Steenkamp, Y., 2011, 'Of poetics and possibility: Richard Kearney's “Re-imagining God"', Unpublished M.Div dissertation, University of Pretoria.

Steenkamp, Y., 2012, 'The God who neither is, nor is not: A theological evaluation of Richard Kearney's "God Who May Be", MTh dissertation, University of Pretoria. Published: Steenkamp, 2014

Steenkamp, Y., 2014, The God who neither is, nor is not: A theological evaluation of Richard Kearney's God Who May Be, African Theological Monographs 3, Scholarium, Cluj-Napoca, România.

Steenkamp, Y., 2016, 'Post-metaphysical God-talk and its implications for Christian theology: Sin and salvation in view of Richard Kearney's God Who May Be', Unpublished PhD thesis, University of Pretoria.

Stewart, A.W., 2012, 'Eve and her interpreters', in C.A. Newsom, S.H. Ringe, \& J.E. Lapsley (eds.), Women's Bible commentary, Rev. \& updated edn., pp. 46-50, Westminster John Knox Press, Louisville, KY.

Toews, J.E., 2013, The story of original sin, James Clarke \& Co, Cambridge.

Van Aarde, A., 2001, Fatherless in Galilee: Jesus as Child of God, Trinity Press International, Harrisburg.

Wilson, B.E., 2012, 'Mary and her interpreters', in C.A. Newsom, S.H. Ringe, \& J.E. Lapsley (eds.), Women's Bible commentary, Rev. \& updated edn., pp. 512-516, Westminster John Knox Press, Louisville, KY 